\section{Elevated Air Temperatures Cause Foliar Bleaching of Ivy Geranium 'Beach' and 'Butterfly'}

\author{
Ritu Dhir and Richard L. Harkess ${ }^{1}$ \\ Department of Plant and Soil Sciences, Mississippi State University, 117 \\ Dorman, Box 9555, Mississippi State, MS 39762
}

\section{Guihong Bi}

Truck Crops Branch Experiment Station, Mississippi State University, 2024 Experiment, Station Road, P.O. Box 231, Crystal Springs, MS 39059

Additional index words. Pelargonium peltatum, heat stress, root-zone temperature, Fe-chelate, chlorophyll, carotenoids

\begin{abstract}
Bleaching of the youngest leaves of actively growing ivy geranium (Pelargonium peltatum L.) develops as the temperature increases from late spring to summer in the southeastern United States. Heat stress-induced iron deficiency has been suspected as causing this disorder. Ivy geranium 'Beach' (bleaching-resistant) and 'Butterfly' (bleaching-susceptible) were grown for 8 weeks at 24 or $31^{\circ} \mathrm{C}$ average root-zone temperature and iron chelate (Fe-EDDHA, $6 \% \mathrm{Fe}$ ) was applied at $0 \mathrm{mg}$ Fe (control), $0.54 \mathrm{mg}$ Fe foliar spray, $1.08 \mathrm{mg}$ Fe foliar spray, $54 \mathrm{mg}$ Fe drench, or $108 \mathrm{mg}$ Fe drench per plant at 30-day intervals. In a second experiment, ivy geranium 'Beach' and 'Butterfly' plants were grown for 6 weeks at $28{ }^{\circ} \mathrm{C}$ day $/ 16^{\circ} \mathrm{C}$ night or $36^{\circ} \mathrm{C}$ day $/ 22{ }^{\circ} \mathrm{C}$ night average air temperatures and iron chelate (Fe-EDDHA, $6 \% \mathrm{Fe}$ ) was applied at $0 \mathrm{mg}$ (control) or $27 \mathrm{mg}$ Fe soil drench per pot at 15-day intervals. No bleaching was observed as a result of elevated root-zone temperatures. High levels of Fe-chelate suppressed growth reducing fresh weight, dry weight, and fresh-to-dryweight ratio in 'Butterfly'. Elevated air temperatures severely reduced plant growth, leaf area, fresh weight, and dry weight in both cultivars. Elevated air temperature reduced chlorophyll a, carotenoids, and pheophytins in 'Butterfly' but not in 'Beach'. Fe-chelate application had no effect at ambient temperature but increased chlorophyll to carotenoids ratio (Chl:Caro) at elevated air temperatures in 'Butterfly'. Therefore, elevated air temperatures were determined to be the cause of bleaching in ivy geranium.
\end{abstract}

Ivy geranium (Pelargonium peltatum L.) is an important floriculture crop but it does not tolerate the high temperatures of southeastern U.S. summers. Under heat stress, the newly developing leaves of ivy geranium are partially or completely white, expand less, and cup upward. This physiological disorder is referred to as "bleaching." Plants may resume developing green leaves when the temperatures moderate. Observational evidence indicated that applying $\mathrm{Fe}$-chelate before bleaching helped reduce the extent of bleaching, which is thought to be Fe-deficiency induced by elevated temperatures (Harvey Lang, Syngenta Flowers, Inc., Boulder, CO, personal communication). Neither the direct cause of this problem nor the role of $\mathrm{Fe}$ in bleaching is known.

High root-zone temperatures above $30^{\circ} \mathrm{C}$ profoundly affect plant growth by reducing root growth (Mathers, 2003). Roots of bentgrass

\footnotetext{
Received for publication 26 Aug. 2010. Accepted for publication 27 Dec. 2010.

We thank Syngenta Flowers, Inc. (Boulder, CO) for donating the plant material used in this research. Contribution of the Mississippi Agriculture and Forestry Experiment Station Journal Series No. J-11886.

${ }^{1}$ To whom reprint requests should be addressed; e-mailrharkess@pss.msstate.edu.
}

are more sensitive to high temperatures than shoots and a decline in root growth has been found to precede that of shoots under heat stress (Carrow, 1996; Xu and Huang, 2000). Solanum species screened for heat tolerance indicated considerable variation in the degree of chlorosis developing as a response to hightemperature stress (Reynolds et al., 1990).

High temperatures inhibit photosynthesis (Sharkey et al., 2001) and the response to high temperatures can vary significantly within a species (Reynolds et al., 1990). High temperatures influenced chloroplast development, chlorophyll biosynthesis, and the greening process (Mohanty et al., 2006). Air temperatures of $41.2{ }^{\circ} \mathrm{C}$ induced chlorosis in tree fern (Cyathea cooperi) and resulted in reduced chlorophyll $(\mathrm{Chl})$ concentration, reduced $\mathrm{Chl}$ a:b ratio, fewer grana, and almost completely absent stroma thylakoids (Doley, 1983).

Iron uptake decreased with increasing root zone temperatures (Raeini-Sartaz and Barthakur, 1995; Tagliavini et al., 1991). Lettuce grown with high ambient root-zone temperatures normally show symptoms of Fe deficiency (He and Lee, 1998a, 1998b). Translocation of Fe within the plant is dependent both on root temperature and the presence of Fe (Schmidt and Steinbach, 2000). Elevated levels of $\mathrm{Fe}$ in the nutrient solution increased tissue chlorophyll content in Pel- argonium $\times$ hortorum (Lee et al., 1996) and chile peppers (Anchondo et al., 2001). Fe deficiency is accompanied by a decrease in all membrane components, including the electron carriers in the photosynthetic electron transport chain (Spiller and Terry, 1980) and light-harvesting pigments, chlorophylls, and carotenoids (Morales et al., 1990, 1994).

Although considerable research has been conducted on Fe nutrition and heat stress, the role of $\mathrm{Fe}$ and heat stress in bleaching of ivy geranium is unknown. The objectives of this study were to determine if elevated root-zone or air temperatures cause bleaching of ivy geranium and to determine the effectiveness of Fe-chelate in preventing bleaching of ivy geraniums.

\section{Materials and Methods}

Elevated root-zone temperature. Rooted cuttings of ivy geraniums 'Beach', a bleaching-resistant cultivar, and 'Butterfly', a bleaching-susceptible cultivar (personal observations) (Syngenta Flowers, Boulder, CO), were planted on 23 Sept. 2005 into 1-L (15-cm diam.) containers in a sphagnum peat:perlite $(70: 30 \mathrm{v} / \mathrm{v})$ substrate amended with 0.96 $\mathrm{kg} \cdot \mathrm{m}^{-3}$ gypsum, $7.7 \mathrm{~kg} \cdot \mathrm{m}^{-3}$ limestone, and $0.32 \mathrm{~kg} \cdot \mathrm{m}^{-3}$ wetting agent (SaturAid; Debco Pty. Ltd., Tyabb, Australia). Plants were fertigated with $250 \mathrm{mg} \cdot \mathrm{L}^{-1}$ nitrogen $(\mathrm{N})$ from 20N-4.4P-16.6K (Peters Peat-lite fertilizer; Scotts Company, Marysville, $\mathrm{OH}$ ) at every irrigation.

The plants were grown in a double-layer, inflated, polyethylene greenhouse with $23{ }^{\circ} \mathrm{C}$ $\mathrm{d}$ and $20^{\circ} \mathrm{C}$ night venting temperatures for 6 weeks to allow root development. Woodframed boxes $(1 \times 1 \times 0.1 \mathrm{~m})$ were constructed with heating cables (Gro-Quick Cables; WrapOn Company, Bedford Park, IL) running inside the box under an insulating foam layer with $15-\mathrm{cm}$ holes cut in which the containers were placed to isolate the foliage from the elevated root-zone temperatures. The substrate surface was exposed from the top of the foam. Average root-zone temperatures were $24{ }^{\circ} \mathrm{C}$ (ranging from 17 to $37^{\circ} \mathrm{C}$ ) and $31{ }^{\circ} \mathrm{C}$ (ranging from 25 to $41{ }^{\circ} \mathrm{C}$ ) for the control and elevated root-zone temperature treatments, respectively. One replication of temperature was represented by one box with the two cultivars, five Fe treatments, and two Fe treatment subsamples for 20 plants per box. There were three replications (boxes) per temperature treatment for a split plot experimental design split by temperature. Plants were placed in the box frames on 29 Oct. 2005 and root-zone temperature treatments started. Iron (Sprint 138, Fe-EDDHA, 6\% Fe; Becker Underwood Inc., Ames, IA) was applied at $0 \mathrm{mg} \mathrm{Fe}$ (control), $0.54 \mathrm{mg} \mathrm{Fe}$ foliar spray, $1.08 \mathrm{mg} \mathrm{Fe}$ foliar spray, $54 \mathrm{mg} \mathrm{Fe}$ medium drench, or $108 \mathrm{mg}$ Fe medium drench per pot on 3 Nov. and 3 Dec. 2005. The 0.54 $\mathrm{mg} \mathrm{Fe}$ foliar spray and $54 \mathrm{mg} \mathrm{Fe}$ medium drenches (i.e., $0.90 \mathrm{~g}$ Fe-chelate dissolved in $60 \mathrm{~mL}$ of distilled water) were calculated from the labeled rates of Sprint 138 for ornamentals. A surfactant $\left(\mathrm{X}-77\right.$ at $0.65 \mathrm{~mL} \cdot \mathrm{L}^{-1}$; Loveland 
Industries Ltd., Greeley, CO) was added to the $\mathrm{Fe}$-chelate foliar sprays.

Data on plant growth were collected at the termination of the study on 22 Dec. 2005. Growth index was calculated as: GI $\left(\mathrm{cm}^{3}\right)=$ $3.14 *(\text { width } / 2)^{2 *}$ height, in which plant height was measured from the rim of the container and width as an average of two widths measured, one at the widest point and another at $90^{\circ}$. Relative growth rate was measured as a difference in growth index (GI) of two consecutive biweekly measurements. Plants were harvested by cutting at the substrate line on 22 Dec. 2005 to determine fresh weights. The harvested plants were dried at $60^{\circ} \mathrm{C}$ until no further change in dry weight for dry weight measurements. The experiment was a split plot design split by temperature with three replications. Data were analyzed using Proc-mixed (SAS software; SAS Institute, Cary, NC) and means separation using Fisher's protected least significant difference at $P=0.05$.

Elevated air temperature. Rooted cuttings of ivy geranium 'Beach' and 'Butterfly' were potted on 15 Dec. 2006 into 1-L (15-cm diam.) pots in the same media previously described. Plants were fertilized with $250 \mathrm{mg} \cdot \mathrm{L}^{-1} \mathrm{~N}$ from 20N-4.4P-16.6K (Peters peat-lite fertilizer; Scotts Company) as a continuous liquid feed. The cuttings were grown for 6 weeks to develop a substantial root system before beginning experimental treatments.

Inside a double-layer polyethylene-covered Quonset greenhouse, six growth chambers $(1.37 \mathrm{~m}$ width $\times 1.22 \mathrm{~m}$ length $\times 0.91 \mathrm{~m}$ height $)$ were constructed using a single-layer, $4-\mathrm{mm}$ clear polyethylene, over polyvinyl chloride tubing. Heating cables (Gro-Quick Cables; Wrap-On Company) were run below, on top of, and $10 \mathrm{~cm}$ above the lath bench top to heat the growth chambers. Chamber sidewalls were raised or lowered to regulate temperature. Air temperature was recorded at hourly intervals with WatchDog data loggers (Model 125; Spectrum Technologies, Plainfield, IL). The shielded temperature sensors were placed at canopy level. The air temperature treatments were $28{ }^{\circ} \mathrm{C} \mathrm{d} / 16{ }^{\circ} \mathrm{C}$ night (ranging from $18.6 / 13.7{ }^{\circ} \mathrm{C}$ to $32.2 / 19.8{ }^{\circ} \mathrm{C} \mathrm{d}$ /night) and $36{ }^{\circ} \mathrm{C} \mathrm{d} / 22^{\circ} \mathrm{C}$ night (ranging from 25.3 / $18.4^{\circ} \mathrm{C}$ to $40.5 / 26.5^{\circ} \mathrm{C} \mathrm{d}$ /night) in the control and elevated air temperature treatments, respectively. Light intensity ranged between 400 and $800 \mu \mathrm{mol} \cdot \mathrm{s}^{-1} \cdot \mathrm{m}^{-2}$ photosynthetic photon flux inside the growth chambers at canopy level when measured between 1000 and 1400 HR from 2 Feb. to 16 Mar. Fe-chelate (Sprint 138, Fe-EDDHA, 6\% Fe; Becker Underwood Inc., Ames, IA) was applied at $0 \mathrm{mg}$ Fe $(60 \mathrm{~mL}$ distilled water application) or $27 \mathrm{mg} \mathrm{Fe}$ (i.e., $0.45 \mathrm{~g} \mathrm{Fe}$-chelate dissolved in $60 \mathrm{~mL}$ of distilled water) drench per container at 15 -d intervals starting 1 Feb. 2007. These Fe rates were half of the labeled dose applied in previous experiments because we observed a bronzing of leaves in all previous drench treatments (personal observation). Plants were placed in the growth chambers on 2 Feb. 2007 and grown for 6 weeks.

Data for plant height, width, and GI were collected as described in the previous ex- periment. The extent of bleaching was determined 6 weeks after treatments (WAT) started as a visual rating on a scale of 1 to 7 , in which $1=0 \%, 2=1 \%$ to $17 \%, 3=18 \%$ to $34 \%, 4=35 \%$ to $50 \%, 5=51 \%$ to $67 \%, 6=$ $68 \%$ to $84 \%$, and $7=85 \%$ to $100 \%$ bleaching. For pigment analysis, one $38.5-\mathrm{mm}^{2}$ leaf disk was collected from each of five recently matured leaves from each plant and pooled for pigment analysis. Each leaf disk was cut into five to six small pieces to aid pigment extraction. The five leaf disks were placed in a vial with $10 \mathrm{~mL} 80 \%$ acetone and incubated at $20{ }^{\circ} \mathrm{C}$ in the dark to allow complete pigment extraction [i.e., Chl $a, \mathrm{Chl} b$, and carotenoids (Caro)]. The pigment concentrations were determined at 663, 645, and $470 \mathrm{~nm}$ (Hill, 1963) using a Bio-Rad ultraviolet/VIS spectrophotometer (Bio-Rad Laboratories, Hercules, CA). Eighty percent acetone was used as the blank. Total pheophytins content of leaves was also determined spectrophotometrically following the methodology of Vernon (1960).

Plants were harvested at the substrate line 6 WAT, 16 Mar. 2007. Total leaf area was determined using a portable leaf area meter (LI-3000; LI-COR, Lincoln, NE). Specific leaf area (SLA) was calculated as the ratio of leaf area to leaf dry weight (Hunt, 1982). Plant tissues were dried in an oven at $60{ }^{\circ} \mathrm{C}$ until no change in dry weight was recorded. Dry leaves were ground through a $0.5-\mathrm{mm}$ screen $(20$ mesh) using a Cyclotec sample mill (UDY Corporation, Fort Collins, $\mathrm{CO}$ ) and total $\mathrm{Fe}$ was determined using inductively coupled plasma atomic emission spectrometry (Optima 4300DV; Perkin Elmer Instruments, Norwalk, CT) (Crouse, 2001).

The experiment was a split plot design, split by temperature with two subsamples of the Fe treatments and three replications. Individual plants were used as experimental units. Data were analyzed using Proc-Glimmix (SAS software; SAS Institute, Cary, NC) and means separation using Fisher's protected least significant difference at $P=0.05$.

\section{Results and Discussion}

Elevated root-zone temperature. There were no interactive effects of temperature and Fe-chelate application on fresh weight, dry weight, or fresh-to-dry-weight ratio. No differences were observed in fresh weight, dry weight, or fresh-to-dry-weight ratio for either cultivar as a result of elevated root- zone temperatures (data not presented). Tahir et al. (2005) found elevated $\left(38^{\circ} \mathrm{C}\right)$ root-zone temperatures had no effect on plant biomass, grain yield, or weight of wheat genotypes 'Fang' (heat-tolerant) or 'Siete Cerros' (heatsensitive). 'Beach' and 'Butterfly' continued growing under elevated root-zone temperatures with no effect on their growth. No bleaching symptoms were observed at the end of the experiment indicating that elevated root-zone temperatures do not suppress the growth of ivy geraniums and do not cause bleaching of ivy geraniums.

Fe-chelate treatments did not affect plant fresh weight, dry weight, or fresh-to-dryweight ratio in 'Beach' (Table 1). However, in 'Butterfly', fresh weight, dry weight, and fresh-to-dry-weight ratio was greater in the control plants and low rate Fe foliar applications than in plants receiving $\mathrm{Fe}$ drench applications (Table 1). Cultivars of marigold also presented different tolerances to $\mathrm{Fe}$-chelate levels (Albano et al., 1996). Roomizadeh and Karimian (1996) reported the soil application of Fe-EDDHA either had no significant effect on dry matter of soybean plants or even reduced it. These results are consistent with the findings documented for chickpea, in which Fe levels (foliar and soil application of $\mathrm{FeSO}_{4} \cdot 7 \mathrm{H}_{2} \mathrm{O}$ and Fe-EDDHA, respectively) reduced dry matter yield (Ghasemi-Fasaei et al., 2005).

Elevated air temperature. There was no interaction between elevated air temperatures and $\mathrm{Fe}$-chelate application observed in plant height, width, or GI for either cultivar throughout the experiment. Elevated air temperature reduced plant width in both cultivars after 6 WAT (Table 2). GI was reduced in 'Beach' but not in 'Butterfly' under elevated air temperatures. High air temperatures have been shown to reduce growth of strawberry plants at $40 / 35{ }^{\circ} \mathrm{C}$ (Kadir et al., 2006). The suppression of growth resulting from high temperatures differed among four genotypes of peanut with the reduction in dry matter and harvest index depending on the heat tolerance of the genotype (Craufurd et al., 1999). The reduction in growth of 'Beach' under elevated temperatures 6 WAT may be an adjustment of metabolism or an adaptive response to minimize heat injury and contribute to its resistance to bleaching.

No interactive effects of elevated air temperatures and Fe-chelate application were observed for fresh weight or dry weight in either cultivar. Fresh weight and dry weight

Table 1. Main effects of Fe-EDDHA applied at 30-d intervals on fresh weight, dry weight. and fresh-todry-weight ratio in ivy geranium 'Beach' and 'Butterfly' at the end of the experiment ( 8 weeks after treatments started).

\begin{tabular}{|c|c|c|c|c|c|c|c|}
\hline \multirow{2}{*}{\multicolumn{2}{|c|}{ Fe treatment }} & \multicolumn{3}{|c|}{ Beach } & \multicolumn{3}{|c|}{ Butterfly } \\
\hline & & \multirow{2}{*}{$\begin{array}{c}\text { Fresh wt } \\
(\mathrm{g})\end{array}$} & \multirow{2}{*}{$\begin{array}{l}\text { Dry wt } \\
\text { (g) }\end{array}$} & \multirow{2}{*}{$\begin{array}{c}\text { Fresh:dry } \\
\text { wt ratio }\end{array}$} & \multirow{2}{*}{$\begin{array}{l}\text { Fresh wt } \\
\text { (g) }\end{array}$} & \multirow{2}{*}{$\begin{array}{l}\text { Dry wt } \\
(\mathrm{g})\end{array}$} & \multirow{2}{*}{$\begin{array}{l}\text { Fresh:dry } \\
\text { wt ratio }\end{array}$} \\
\hline Fe-rate & Method & & & & & & \\
\hline$\overline{0 \mathrm{mg}}$ & Control & $232.6 \mathrm{a}^{\mathrm{z}}$ & $24.8 \mathrm{a}$ & $7.31 \mathrm{a}$ & $173.3 \mathrm{a}$ & $17.0 \mathrm{a}$ & $7.35 \mathrm{a}$ \\
\hline $0.54 \mathrm{mg}$ & Foliar & $255.8 \mathrm{a}$ & $27.9 \mathrm{a}$ & $7.61 \mathrm{a}$ & $149.0 \mathrm{a}$ & $14.7 \mathrm{ab}$ & $7.10 \mathrm{a}$ \\
\hline $1.08 \mathrm{mg}$ & Foliar & $231.3 \mathrm{a}$ & $24.8 \mathrm{a}$ & $7.46 \mathrm{a}$ & $143.1 \mathrm{ab}$ & $14.2 \mathrm{ab}$ & $7.00 \mathrm{ab}$ \\
\hline $54 \mathrm{mg}$ & Drench & $249.4 \mathrm{a}$ & $26.4 \mathrm{a}$ & $7.64 \mathrm{a}$ & $113.0 \mathrm{bc}$ & $11.7 \mathrm{bc}$ & $5.95 \mathrm{c}$ \\
\hline $108 \mathrm{mg}$ & Drench & $216.2 \mathrm{a}$ & $22.8 \mathrm{a}$ & $7.26 \mathrm{a}$ & $105.1 \mathrm{c}$ & $10.9 \mathrm{c}$ & $6.19 \mathrm{bc}$ \\
\hline
\end{tabular}

${ }^{\mathrm{z}}$ Means separation within columns using Fisher's protected least significant difference test $(P=0.05)$. $\mathrm{Fe}=$ iron 
Table 2. Main effects of elevated air temperature and Fe-EDDHA applications on width, growth index (GI), fresh weight, dry weight, leaf area (LA), and specific leaf area (SLA) in ivy geranium 'Beach' and 'Butterfly' grown at $28{ }^{\circ} \mathrm{C}$ or $36^{\circ} \mathrm{C}$ and supplied with Fe-chelate at 0 or $27 \mathrm{mg}$ Fe drench per plant.

\begin{tabular}{|c|c|c|c|c|c|c|c|c|c|c|c|c|}
\hline \multirow[b]{2}{*}{ Temperature } & \multicolumn{6}{|c|}{ Beach } & \multicolumn{6}{|c|}{ Butterfly } \\
\hline & $\begin{array}{l}\text { Width } \\
(\mathrm{cm})\end{array}$ & $\begin{array}{c}\mathrm{GI}^{\mathrm{z}} \\
\left(\mathrm{cm}^{3}\right)\end{array}$ & $\begin{array}{c}\text { Fresh wt } \\
(\mathrm{g})\end{array}$ & $\begin{array}{c}\text { Dry wt } \\
\text { (g) }\end{array}$ & $\begin{array}{c}\mathrm{LA} \\
\left(\mathrm{cm}^{2}\right)\end{array}$ & SLA $^{y}$ & $\begin{array}{l}\text { Width } \\
(\mathrm{cm})\end{array}$ & $\mathrm{GI}\left(\mathrm{cm}^{3}\right)$ & $\begin{array}{c}\text { Fresh wt } \\
\text { (g) }\end{array}$ & $\begin{array}{c}\text { Dry wt } \\
\text { (g) }\end{array}$ & $\mathrm{LA}\left(\mathrm{cm}^{2}\right)$ & SLA \\
\hline $28^{\circ} \mathrm{C}$ & $47.4 \mathrm{a}^{\mathrm{x}}$ & $31934 \mathrm{a}$ & $284.3 \mathrm{a}$ & $29.6 \mathrm{a}$ & $3111 \mathrm{a}$ & $141.5 \mathrm{a}$ & $42.8 \mathrm{a}$ & $21996 \mathrm{a}$ & $229.1 \mathrm{a}$ & $22.7 \mathrm{a}$ & $2579 \mathrm{a}$ & $155.9 \mathrm{a}$ \\
\hline $36^{\circ} \mathrm{C}$ & $35.0 \mathrm{~b}$ & $17446 \mathrm{~b}$ & $169.2 \mathrm{~b}$ & $17.5 \mathrm{~b}$ & $1643 \mathrm{~b}$ & $135.8 \mathrm{a}$ & $33.4 \mathrm{~b}$ & 14968 a & $113.0 \mathrm{~b}$ & $12.1 \mathrm{~b}$ & $1192 \mathrm{~b}$ & $136.5 \mathrm{~b}$ \\
\hline \multicolumn{13}{|l|}{ Fe application } \\
\hline $0 \mathrm{mg} \mathrm{Fe}$ & $40.5 \mathrm{a}$ & $24909 \mathrm{a}$ & $221.5 \mathrm{a}$ & $23.3 \mathrm{a}$ & $2417 \mathrm{a}$ & $138.2 \mathrm{a}$ & $38.1 \mathrm{a}$ & $18337 \mathrm{a}$ & $169.4 \mathrm{a}$ & $17.2 \mathrm{a}$ & $1945 \mathrm{a}$ & $147.8 \mathrm{a}$ \\
\hline $27 \mathrm{mg} \mathrm{Fe}$ & $41.9 \mathrm{a}$ & $24471 \mathrm{a}$ & $231.9 \mathrm{a}$ & $23.8 \mathrm{a}$ & $2337 \mathrm{a}$ & $139.1 \mathrm{a}$ & $38.1 \mathrm{a}$ & $18627 \mathrm{a}$ & $172.7 \mathrm{a}$ & $17.6 \mathrm{a}$ & $1826 \mathrm{a}$ & $144.6 \mathrm{a}$ \\
\hline
\end{tabular}

${ }^{\mathrm{z}} \mathrm{GI}\left(\mathrm{cm}^{3}\right)=3.14 *(\text { width } / 2)^{2 *}$ height.

${ }^{y} S L A=$ calculated as the ratio of leaf area to leaf dry weight.

${ }^{\mathrm{x}}$ Means separation within columns and within cultivar using Fisher's protected least significant difference test $(P=0.05)$.

$\mathrm{Fe}=$ iron

were reduced at elevated air temperatures in 'Beach' and 'Butterfly' (Table 2), which has also been found in pansy and strawberry (Hamlin et al., 1999; Kadir et al., 2006).

Leaf area (LA) was reduced at elevated air temperatures in 'Beach' and 'Butterfly' (Table 2) indicating a reduced leaf surface area for transpiration and transpirational cooling. Leaf expansion has been shown to be a function of leaf temperature (Tardieu et al., 1999). Reduction in net $\mathrm{CO}_{2}$ assimilation rate at high temperatures reduced total LA and plant biomass (Kadir et al., 2006). Elevated air temperature reduced biomass accumulation and LA in both cultivars of ivy geranium.

Specific leaf area is a measure of leaf density or relative thickness (Hunt, 1982) and describes the allocation of leaf biomass per unit leaf area (Pierce et al., 1994). SLA was unaffected by temperature in 'Beach' but was reduced in 'Butterfly' grown at elevated air temperatures (Table 2). However, SLA was reduced in 'Butterfly' indicating leaf thickness or leaf density increased in 'Butterfly' at elevated temperature.

Fe-chelate applications did not affect plant width, GI, fresh weight, dry weight, LA, or SLA in either ivy geranium cultivar (Table 2).

There were no interactive effects of elevated air temperature and Fe-chelate application on bleaching of either cultivar. Bleaching symptoms occurred on 'Butterfly' earlier than 'Beach' (personal observation). However, 6 WAT 'Beach' and 'Butterfly' both showed significant bleaching of leaves (Table 3) confirming elevated air temperatures result in bleaching of ivy geranium leaves. Similar findings have documented that heat stress $\left(56{ }^{\circ} \mathrm{C}\right)$ caused bleaching of Pelargonium ×hortorum Bailey (Senaratna et al., 2002). These results were also similar to those reported for tree fern, Cyathea cooperi (Doley, 1983).

No interaction between elevated air temperatures and $\mathrm{Fe}$-chelate application was observed for Chl a, Chl b, Chl a+b, Caro, chlorophyll a to b ratio (Chl a:b), Chl a:Caro, Chl b:Caro, or Chl $(\mathrm{a}+\mathrm{b})$ :Caro in 'Beach'. Elevated air temperature did not reduce $\mathrm{Chl}$ a, Chl b, Chl (a+b), Caro, or Chl a:b in 'Beach' (Table 3). Similar results were found in wheat plants in which no change was observed in total Chl, Chl a:b, and Caro as a result of heat shock at 37 to $38^{\circ} \mathrm{C}$ for $3 \mathrm{~h}$ (Kislyuk et al., 2007). No reduction in $\mathrm{Chl} \mathrm{a}, \mathrm{Chl} \mathrm{b}$, or $\mathrm{Chl}$

Table 3. Main effects of elevated air temperature and Fe-EDDHA applications on extent of bleaching, chlorophyll a (Chl a), chlorophyll b (Chl b), total chlorophyll $(\mathrm{Chl} \mathrm{a}+\mathrm{b})$, chlorophyll a to b ratio (Chl $\mathrm{a}: \mathrm{b})$, carotenoids (Caro), and pheophytins concentrations $\left(\mu \mathrm{g} \cdot \mathrm{cm}^{-2}\right)$ of ivy geranium 'Beach' and 'Butterfly' grown at 28 or $36^{\circ} \mathrm{C}$ and supplied with $\mathrm{Fe}$-chelate at 0 or $27 \mathrm{mg} \mathrm{Fe}$ drench per plant at the end of experiment.

\begin{tabular}{cccccccr}
\hline Temperature & $\begin{array}{c}\text { Extent of } \\
\text { bleaching }\end{array}$ & Chl a & Chl b & Chl a+b & Chl a:b & Caro & Pheophytins \\
\hline Beach & & & & & & & \\
$28{ }^{\circ} \mathrm{C}$ & $1.02 \mathrm{~b}^{\mathrm{z}}$ & $22.82 \mathrm{a}^{\mathrm{z}}$ & $13.41 \mathrm{a}$ & $36.23 \mathrm{a}$ & $1.70 \mathrm{a}$ & $7.76 \mathrm{a}$ & $25.69 \mathrm{a}$ \\
$36^{\circ} \mathrm{C}$ & $2.08 \mathrm{a}$ & $17.16 \mathrm{a}$ & $10.41 \mathrm{a}$ & $27.58 \mathrm{a}$ & $1.64 \mathrm{a}$ & $7.42 \mathrm{a}$ & $17.40 \mathrm{a}$ \\
Butterfly & & & & & & & \\
$28^{\circ} \mathrm{C}$ & $1.08 \mathrm{~b}$ & $19.63 \mathrm{a}$ & $11.24 \mathrm{a}$ & $30.87 \mathrm{a}$ & $1.75 \mathrm{a}$ & $6.89 \mathrm{a}$ & $18.51 \mathrm{a}$ \\
$36{ }^{\circ} \mathrm{C}$ & $4.17 \mathrm{a}$ & $10.94 \mathrm{~b}$ & $6.46 \mathrm{a}$ & $17.39 \mathrm{~b}$ & $1.87 \mathrm{a}$ & $4.57 \mathrm{~b}$ & $3.56 \mathrm{~b}$
\end{tabular}

Fe application

Beach

\begin{tabular}{rrrrrrrr}
$0 \mathrm{mg} \mathrm{Fe}$ & $1.63 \mathrm{a}$ & $18.76 \mathrm{a}^{\mathrm{z}}$ & $11.06 \mathrm{a}$ & $29.82 \mathrm{a}$ & $1.69 \mathrm{a}$ & $7.12 \mathrm{a}$ & $18.93 \mathrm{a}$ \\
$27 \mathrm{mg} \mathrm{Fe}$ & $1.48 \mathrm{a}$ & $21.22 \mathrm{a}$ & $12.76 \mathrm{a}$ & $33.99 \mathrm{a}$ & $1.65 \mathrm{a}$ & $8.06 \mathrm{a}$ & $24.16 \mathrm{a}$ \\
Butterfly & & & & & & & \\
$0 \mathrm{mg} \mathrm{Fe}$ & $2.71 \mathrm{a}$ & $14.92 \mathrm{a}$ & $8.28 \mathrm{a}$ & $23.21 \mathrm{a}$ & $1.98 \mathrm{a}$ & $5.75 \mathrm{a}$ & $12.64 \mathrm{a}$ \\
$27 \mathrm{mg} \mathrm{Fe}$ & $2.54 \mathrm{a}$ & $15.64 \mathrm{a}$ & $9.41 \mathrm{a}$ & $25.06 \mathrm{a}$ & $1.64 \mathrm{a}$ & $5.71 \mathrm{a}$ & $9.23 \mathrm{a}$ \\
\hline
\end{tabular}

${ }^{\mathrm{z}}$ Means separation within columns, cultivar, and treatment main effects using Fisher's protected least significant difference test $(P=0.05)$.

${ }^{y}$ Extent of bleaching measured on a visual scale of 1 to 7 in which $1=0 \%, 2=1 \%$ to $17 \%, 3=18 \%$ to $34 \%$, $4=35 \%$ to $50 \%, 5=51 \%$ to $67 \%, 6=68 \%$ to $84 \%$, and $7=85 \%$ to $100 \%$ bleaching.

$\mathrm{Fe}=$ iron.

$(\mathrm{a}+\mathrm{b})$ resulting from elevated temperatures may be explained by an overestimation of $\mathrm{Chl}$ in the chlorotic leaves as a result of reduced plant growth. However, in 'Butterfly', the concentrations of $\mathrm{Chl}$ a and $\mathrm{Chl}$ $(\mathrm{a}+\mathrm{b})$ were reduced when grown at elevated air temperatures, whereas no differences were observed for Chl b (Table 3). In addition, 'Butterfly' GI was not reduced when grown under elevated temperatures. These findings suggest that $\mathrm{Chl}$ a has greater sensitivity in 'Butterfly' to high temperature than Chl b. A reduction in leaf chlorophyll resulting from heat stress was also reported in bentgrass (Xu and Huang, 2007) and was found to occur as a result of impairment of Chl biosynthetic enzymes by heat stress in cucumber seedlings (Tewari and Tripathy, 1998).

No differences were observed in Caro concentration in 'Beach' as a result of elevated air temperature, but there was a reduction in carotenoids concentration in 'Butterfly' (Table 3 ), a result also observed in heat-stressed, chlorotic rye plants (Feieraband, 1977). Maintenance of Chl and Caro in 'Beach', a resistant cultivar, under elevated air temperatures may support the view of Wahid (2007) that Caro under heat stress protect the $\mathrm{Chl}$ biosynthetic machinery and ensure intactness of thylakoid membrane components. The reduction of $\mathrm{Chl}$ and Caro in 'Butterfly', a susceptible cultivar, supports the findings that a reduction in Caro may not give sufficient protection resulting in damage to Chl (Feieraband, 1977). Considering the lack of change in $\mathrm{Chl} \mathrm{a,} \mathrm{Chl}(\mathrm{a}+\mathrm{b})$, and Caro in 'Beach' and reduction in $\mathrm{Chl} \mathrm{a}, \mathrm{Chl}$ $(\mathrm{a}+\mathrm{b})$, and Caro in 'Butterfly' as a result of elevated air temperature, it is plausible that Caro, in addition to harvesting light, provide a protective advantage against heat-induced damage.

$\mathrm{Fe}$-chelate applications did not affect extent of bleaching, Chl a, Chl b, Chl $(\mathrm{a}+\mathrm{b})$, Caro, or Chl a:b in 'Beach' or 'Butterfly' (Table 3). Pheophytin concentrations declined in 'Butterfly' under elevated air temperatures but were unaffected in 'Beach' (Table 3). The photo-reducible pheophytin is the primary electron acceptor of PSII in the early steps of the photosynthetic solar energy conversion, acting between P680 and plastoquinone (Klimov, 2003). The decline in pheophytins in ivy geranium 'Butterfly' grown under elevated air temperatures may indicate a heat-induced functional disconnection in electron transfer in PSII. Fe-chelate application did not affect pheophytin content in either cultivar (Table 3 ). 
Table 4. Interaction effects of elevated air temperature and Fe-EDDHA soil drench application on total foliar Fe content of ivy geranium 'Beach'.

\begin{tabular}{lcc}
\hline Temperature & $\begin{array}{c}\mathrm{Fe} \\
(\mathrm{mg} \text { per pot) }\end{array}$ & $\begin{array}{c}\text { Total Fe } \\
\left(\mathrm{mg} \cdot \mathrm{L}^{-1}\right)\end{array}$ \\
\hline $28^{\circ} \mathrm{C}$ & 0 & $58.52 \mathrm{~b}^{\mathrm{z}}$ \\
$28^{\circ} \mathrm{C}$ & 27 & $64.12 \mathrm{~b}$ \\
$36^{\circ} \mathrm{C}$ & 0 & $59.99 \mathrm{~b}$ \\
$36^{\circ} \mathrm{C}$ & 27 & $99.15 \mathrm{a}$ \\
\hline
\end{tabular}

${ }^{\mathrm{z}}$ Means separation within column using Fisher's protected least significant difference test $(P=0.05)$. $\mathrm{Fe}=$ iron.

Table 5. Main effects of elevated air temperature and Fe-EDDHA application on foliar total $\mathrm{Fe}$ content of ivy geranium 'Butterfly' grown at temperatures of 28 or $36^{\circ} \mathrm{C}$ and supplied with Fe-chelate at 0 or $27 \mathrm{mg} \mathrm{Fe}$ per plant as soil drench.

\begin{tabular}{lc}
\hline Temperature & $\mathrm{Fe}\left(\mathrm{mg} \cdot \mathrm{L}^{-1}\right)$ \\
\hline $28{ }^{\circ} \mathrm{C}$ & $67.43 \mathrm{a}^{\mathrm{z}}$ \\
$36{ }^{\circ} \mathrm{C}$ & $72.28 \mathrm{a}$
\end{tabular}

Fe application

$0 \mathrm{mg} \mathrm{Fe}$

$55.09 \mathrm{~b}$

$27 \mathrm{mg} \mathrm{Fe}$

$80.66 \mathrm{a}$

${ }^{\mathrm{z}}$ Means separation within column using Fisher's protected least significant difference test $(P=0.05)$. $\mathrm{Fe}=$ iron.

Fe-chelate application did increase foliar total Fe concentration in 'Beach' and 'Butterfly' (Tables 4 and 5). Total foliar Fe content in 'Beach' was a function of temperature and $\mathrm{Fe}$-chelate application (Table 4). Foliar Fe in 'Beach' was only elevated when Fe-chelate was applied under elevated temperatures. This indicates that the Fe uptake from the soil solution was not inhibited during conditions causing bleaching in ivy geranium.

There was no interaction of temperature and $\mathrm{Fe}$-chelate application on foliar $\mathrm{Fe}$ in 'Butterfly' (Table 5). Despite 'Butterfly' experiencing greater severity of leaf bleaching, foliar Fe content was unchanged by elevated temperatures indicating Fe uptake was unaffected by temperature. However, application of $\mathrm{Fe}$-chelate did increase foliar Fe concentration in 'Butterfly'. Similar total foliar Fe concentrations in 'Butterfly' plants grown at ambient and elevated air temperatures may be supported by the "Chlorosis paradox" in which chlorotic plants had greater total Fe than green plants (Romheld, 2000). Chlorosis in leaves is caused not only by insufficient uptake or translocation of $\mathrm{Fe}$ from roots to aerial parts, but also from the failure of the leaves to reduce $\mathrm{Fe}^{3+}$. Zohlen (2002) concluded the chlorosis to be a physiological Fe deficiency caused by the mobilization of $\mathrm{Fe}$ to a metabolically inactive form in the plant tissues. In heat-stressed ivy geraniums, chelate reductase activity may be suppressed resulting in inactivation of Fe. This suggests that total $\mathrm{Fe}$ content may not be the best indicator of $\mathrm{Fe}$ status in ivy geraniums with bleaching. Active $\mathrm{Fe}$ may be a more sensitive parameter to plant $\mathrm{Fe}$ status than total $\mathrm{Fe}$ (Smith and Cheng, 2006).

In conclusion, bleaching in ivy geraniums is a symptom of heat stress first expressed in young developing leaves and is caused by prolonged exposure to elevated air temperatures. Although growth was inhibited, Fe uptake was not inhibited as a result of elevated air temperatures or bleaching.

\section{Literature Cited}

Albano, J.P., W.B. Miller, and M.C. Halbrooks. 1996. Iron toxicity stress causes bronze speckle, a specific physiological disorder of marigold (Tagetes erecta L.). J. Amer. Soc. Hort. Sci. 121:430-437.

Anchondo, J.A., M.M. Wall, V.P. Gutschick, and D.W. Smith. 2001. Pigment accumulation and micronutrient concentration of iron deficient chile peppers in hydroponics. HortScience 36: 1206-1210.

Carrow, R.N. 1996. Summer decline of bentgrass greens. Golf Course Management 64:51-56.

Craufurd, P.Q., T.R. Wheeler, R.H. Ellis, R.J. Summerfield, and J.H. Williams. 1999. Effect of temperature and water deficit on water-use efficiency, carbon isotope discrimination and specific leaf area in peanut. Crop Sci. 39:136142.

Crouse, K.K. 2001. Soil testing and plant analysis in Mississippi: Procedures used by the MSUES soil testing laboratory. Mississippi State University, Mississippi State, MS.

Doley, D. 1983. Chlorosis in a tree fern (Cyathea cooperi) induced by brief heat stress. Aust. J. Bot. 31:23-33.

Feieraband, J. 1977. Capacity for chlorophyll synthesis in heat-bleached $70 \mathrm{~S}$ ribosome-deficient rye leaves. Planta 135:83-88.

Ghasemi-Fasaei, R., A. Ronaghi, M. Maftoun, N. Karimian, and P.N. Soltanpour. 2005. Ironmanganese interaction in chickpea as affected by foliar and soil application of iron in a calcareous soil. Commun. Soil Sci. Plant Anal. 36: $1717-1725$.

Hamlin, R.L., H.A. Mills, and W.M. Randle. 1999. Growth and nutrition of pansy as influenced by $\mathrm{N}$-form ratio and temperature. J. Plant Nutr. 22: $1637-1650$.

He, J. and S.K. Lee. 1998a. Growth and photosynthetic characteristics of lettuce under fluctuating hot ambient temperature with manipulation of cool root-zone temperature. J. Plant Physiol. 152:387-391

He, J. and S.K. Lee. 1998b. Growth and photosynthetic responses of 3 aeroponically grown lettuce cultivars (Lactuca sativa $\mathrm{L}$.) to different root-zone temperatures and growth irradiances under tropical aerial conditions. J. Hort. Sci. Biotechnol. 73:173-180.

Hill, R. 1963. Chlorophyll, p. 73-97. In: Florkin, M. and E.H. Stotz (eds.). Comprehensive biochemistry. Elsevier Publishing Company, Amsterdam, The Netherlands, and London, UK.

Hunt, R. 1982. Plant growth curves: The functional approach to plant growth analysis. Edward Arnold (Publishers) Limited, London, UK.

Kadir, S., G. Sidhu, and K. Al-Khatib. 2006. Strawberry (Fragaria $\times$ ananassa Duch.) growth and productivity as affected by temperature. HortScience 41:1423-1430.

Kislyuk, I.M., L.S. Bubolo, I.E. Kamentseva, E.R Kotlova, and O.A. Sherstneva. 2007. Heat shock increases thermotolerance of photosynthetic electron transport and content of chloroplast membranes and lipids in wheat leaves. Russ. J. Plant Physiol. 54:456-463.

Klimov, V.V. 2003. Discovery of pheophytin function in the photosynthetic energy conversion as the primary electron acceptor of photosystem II. Photosynth. Res. 76:247-253.

Lee, C.W., J.M. Choi, and C.H. Pak. 1996. Micronutrient toxicity in seed geranium (Pelargonium $\times$ hortorum Bailey). J. Amer. Soc. Hort. Sci. 121: $77-82$.

Mathers, H.M. 2003. Summary of temperature stress issues in nursery containers and current methods of protection. HortTechnology 13: 617-624.

Mohanty, S., B. Grimm, and B.C. Tripathy. 2006. Light and dark modulation of chlorophyll biosynthetic genes in response to temperature. Planta 224:692-699.

Morales, F., A. Abadia, and J. Abadia. 1990. Characterization of the xanthophylls cycle and other photosynthetic pigment changes induced by iron deficiency in sugarbeet (Beta vulgaris). Plant Physiol. 94:607-613.

Morales, F., A. Abadia, and J. Abadia. 1994. Iron deficiency induced change in photosynthetic pigment composition of field-grown pear (Pyrus communis L.) leaves. Plant Cell Environ. 17: 1153-1160.

Pierce, L.L., S.W. Running, and J. Walker. 1994. Regional scale relationships of leaf area index to specific leaf area and leaf nitrogen content. Ecol. Appl. 4:313-321.

Raeini-Sartaz, M. and N.N. Barthakur. 1995. Antagonistic effects of root zone temperature and iron on phosphorus uptake by bush bean. J. Plant Nutr. 18:1315-1321.

Reynolds, M.P., E.E. Ewing, and T.G. Owens. 1990. Photosynthesis at high temperature in tuber-bearing Solanum species: A comparison between accessions of contrasting heat tolerance. Plant Physiol. 93:791-797.

Romheld, V. 2000. The chlorosis paradox: Fe inactivation as a secondary event in chlorotic leaves of grapevines. J. Plant Nutr. 23:1629-1643.

Roomizadeh, S. and N. Karimian. 1996. Manganese-iron relationship in soybean grown in calcareous soils. J. Plant Nutr. 19:397-406.

Schmidt, W. and S. Steinbach. 2000. Sensing iron-A whole plant approach. Ann. Bot. (Lond.) 86:589-593.

Senaratna, T., E. Bunn, and A. Bishop. 2002. Triazole treatment of explant source provides stress tolerance in progeny of geranium ( $\mathrm{Pel}$ argonium hortorum Bailey) plants regenerated by somatic embryogenesis. Plant Growth Regulat. 36:169-174.

Sharkey, T.D., M.R. Badger, S. von Caemmerer, and T.J. Andrew. 2001. Increased heat sensitivity of photosynthesis in tobacco plants with reduced Rubisco activase. Photosynth. Res. 67: 147-156.

Smith, B.R. and L. Cheng. 2006. Fe-EDDHA alleviates chlorosis in 'Concord' grapevines grown at high $\mathrm{pH}$. HortScience 41:1498-1501.

Spiller, S. and N. Terry. 1980. Limiting factors in photosynthesis, II. Iron stress diminished photochemical capacity by reducing the number of photosynthetic units. Plant Physiol. 65:121-125.

Tagliavini, M., E.J. Hogue, and G.H. Neilsen 1991. Influence of phosphorus nutrition and root zone temperature on growth and mineral uptake of peach seedlings. J. Plant Nutr. 14: $1267-1276$

Tahir, I.S.A., N. Nakata, and T. Yamaguchi. 2005. Responses of three wheat genotypes to high soil temperature during grain filling. Plant Prod. Sci. 8:192-198.

Tardieu, F., C. Garnier, and B. Muller. 1999. Research review: Modeling leaf expansion in a fluctuating environment: Are changes in specific leaf area a consequence of changes in expansion rate? New Phytol. 143:33-43. 
Tewari, A.K. and B.C. Tripathy. 1998. Temperature-stress-induced impairment of chlorophyll biosynthetic reactions in cucumber and wheat. Plant Physiol. 117:851-858.

Vernon, L.P. 1960. Spectrophotometric determination of chlorophylls and pheophytins in plant extracts. Anal. Chem. 32:11441150 .
Wahid, A. 2007. Physiological implications of metabolite biosynthesis for net assimilation and heat-stress tolerance of sugarcane (Saccharum officinarum) sprouts. J. Plant Res. 120:219-228.

$\mathrm{Xu}$, Q. and B. Huang. 2000. Growth and physiological responses of creeping bentgrass to changes in air and soil temperatures. Crop Sci. 40:1363-1368.
Xu, Q. and B. Huang. 2007. Heat-induced leaf senescence and hormonal changes for thermal bentgrass and turf-type bentgrass species differing in heat-tolerance. J. Amer. Soc. Hort. Sci. 132: 185-192.

Zohlen, A. 2002. Chlorosis in wild plants: Is it a sign of iron deficiency? J. Plant Nutr. 25:2205 2228 . 